\title{
Exploring a conceptual model, based on the combined effects of entrepreneurial leadership, market orientation and relationship marketing orientation on South Africa's small tourism business performance
}

\author{
H.J.C. van Zyl and B. Mathur-Helm* \\ University of Stellenbosch Business School, PO Box 610, \\ Bellville 7535, Republic of South Africa \\ babita@usb.sun.ac.za
}

Received January 2007

\begin{abstract}
This article explores the relationships between entrepreneurial leadership, market orientation and relationship marketing orientation and South Africa's Small tourism business performance. The entrepreneurial leadership construct is a product of the fusion of entrepreneurship and leadership constructs. This article firstly explores the relationship of entrepreneurial leadership as an antecedent to the blend of market orientation and relationship marketing orientation on small tourism performance, and secondly the relationship of the combined effects of entrepreneurial leadership, market orientation and relationship marketing orientation on small tourism business performance. It is a descriptive and theoretical article, and thus secondary data from previous studies are used as comparative analysis for examination and discussion. The findings indicate that there is a relationship between the identified constructs. However, the exact nature and extent of these relationships need to be further investigated.
\end{abstract}

*To whom all correspondence should be addressed.

\section{Introduction}

The tourism industry in South Africa is growing and therefore not only provides growth opportunities for existing tourism enterprises, but also for the establishment of new tourism ventures (Naidoo, 2004). According to Naidoo (2004) the contribution of tourism industry to South Africa's Gross Domestic Products (GDP) was 4\% in 1995, which increased to $8,2 \%$ in 1999 . More recently this figure has increased to 10\% of GDP in 2007 (Brown, 2007). Growth in the tourism industry will facilitate job creation, which is much needed in the South African economy. The government views this as an opportunity to create employment and to bring in equality in the country's job market. Business with low capital investments could become sustainable, depending on the skills and characteristics of the owner-managers (entrepreneurs) of these businesses. According to the Small Business Act 109 of 1996, small enterprises in South Africa are regarded as those enterprises that have less than fifty employees (Makhitha, 2001).

Entrepreneurial leadership (Gupta, MacMillan and Surie, 2004; Ireland, Hitt \& Sirmon, 2003; Swiercz \& Lydon, 2002); market orientation (Agarwal, Erramilli \& Dev, 2003; Becherer, Halstead \& Haynes, 2001; Esteban, Millán, Molina \& Martín-Consuegra, 2002; Farrell, 2000; Guo, 2002; Homburg, Krohmer \& Workman, 2004; Lafferty \& Hult, 2001; Langerak, 2003; Matear, Osborne, Garrett \& Gray, 2002) and relationship marketing orientation (Sin,
Tse, Yau, Lee \& Chow, 2002; Sin, Tse, Yau, Chow \& Lee, 2005; Tse, Sin, Yau, Lee \& Chow, 2004; Zontanos \& Anderson, 2004) have been identified as positive influence on the business performance of an enterprise (Gupta, MacMillan \& Surie, 2004; Ireland, Hitt \& Sirmon, 2003; Swiercz \& Lydon, 2002).

Entrepreneurial leadership refers to the summative characteristics of the 'entrepreneurship' and 'leadership' concepts. These entrepreneurial and leadership characteristics are what Lerner and Harber (2000) call 'the human capital approach' in their study on small business ventures in Israeli tourism. They have identified certain qualities and skills essential for effective performance of a tourism entrepreneur, which also contribute towards small venture performance. These are managerial and personal characteristics, such as internal locus of control, achievement orientation and autonomy. In small and micro enterprises these characteristics for the owner-manager seem to be of vital importance for the venture to perform effectively.

Morrison, Rimmington, and Williams (1999) describe the fit between an entrepreneur, an organization and the environment and its contributions towards the success of a business. The implication is that the smaller the enterprise the bigger is the overlap between the entrepreneur and the organization and subsequently, the role of an ownermanager becomes more important. The nature of interaction 
between the environment and the owner-manager would then determine the extent of business performance.

Another study by Morrison and Teixeira (2004) reports that the motivations, goals and capabilities of the ownermanagers of tourism enterprises influence business performance positively. When Goleman (1998) refers to social skills as key leadership qualities necessary for managing relationships, he also suggests that performing entrepreneurs should additionally be in possession of leadership skills. Wood (2002) in her study establishes a relationship between an entrepreneurial personality, market orientation and tourism enterprise performance, suggesting that the qualities of entrepreneurial leaders are significant to the performance of small tourism enterprises.

Sin, Tse, Yau, Chow, and Lee (2005) describe how the competitive environment moderates the direct impact of market orientation and relationship marketing orientation respectively on business performance. Another study by Tse et al. (2004) found that market orientation and relationship marketing orientation strategies had different influences on market leaders, market challengers, market followers and market niches. The influence of market orientation and relationship marketing orientation as strategic orientations on business performance is therefore important and has not yet been investigated in small South African tourism ventures.

Pulendran, et al. (2000) identified four antecedents of market orientation, namely top management factors, organizational systems, interdepartmental dynamics, and reward system orientation and found them as influencing factors on the market orientation in a small business, either by driving it or by hindering it. This paper however focuses on the skills and characteristics of owner managers of small tourism enterprises through the fused entrepreneurship and leadership constructs.

It is therefore relevant to investigate the skills and characteristics of owner managers/ entrepreneurs/leaders as antecedents of market orientation and relationship marketing orientation. It could therefore be hypothesized that entrepreneurial leadership, market orientation and relationship marketing orientation are closely related to the business performance of small tourism enterprises.

\section{$\begin{array}{lll}\text { Antecedents Strategic Orientations Outcome } & \text { S }\end{array}$}

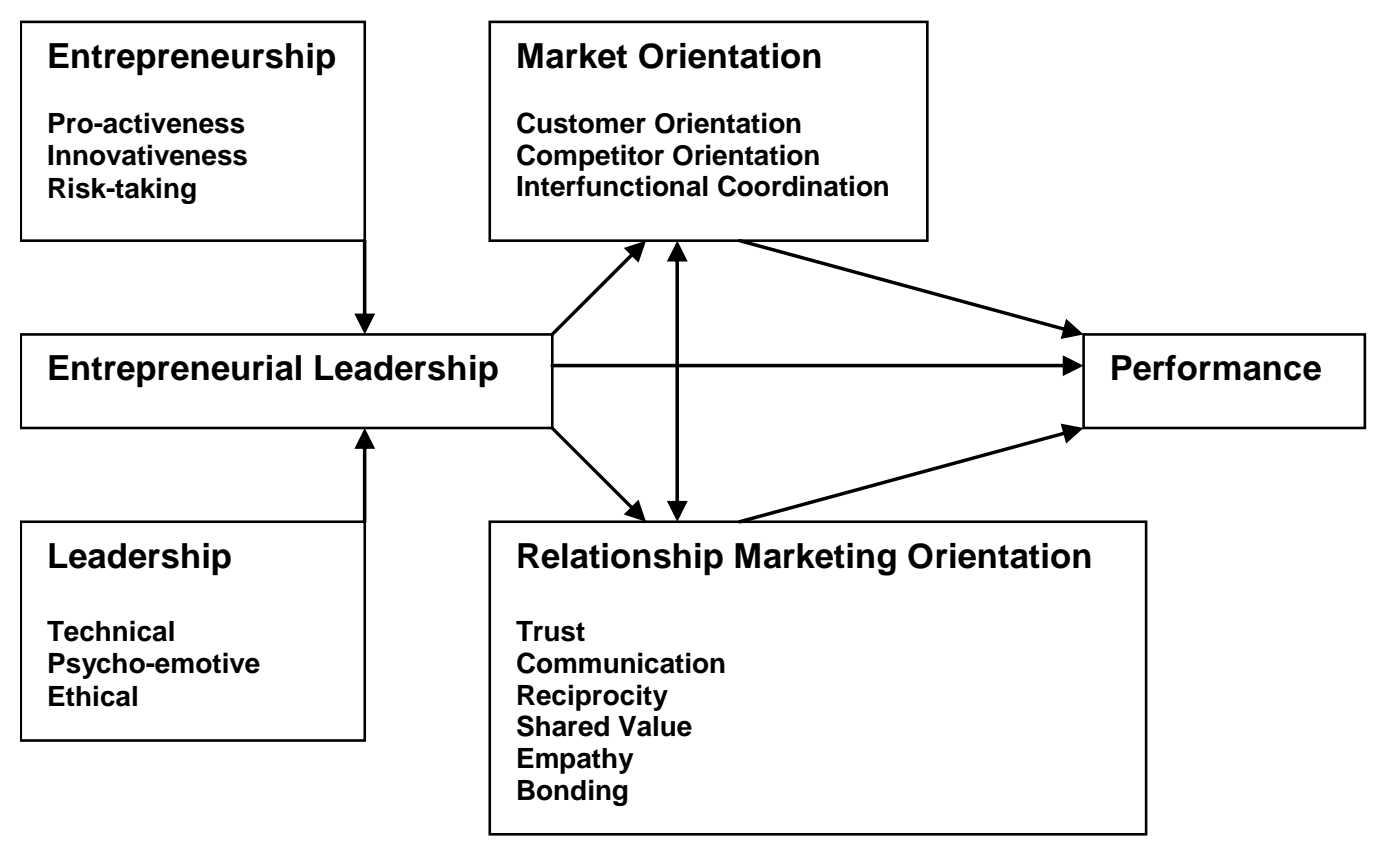

Figure 1: Conceptual model: Linking entrepreneurial leadership with market orientation, relationship marketing orientation and performance

\section{Entrepreneurial leadership}

Several past studies have illustrated a positive relationship between leadership attributes and a variety of performance variables (Gupta et al., 2004; Wolff, Pescosolido \& Druskat, 2002; Harris \& Ogbona, 2001; Barling, et al., 2000; Baum, et al., 1998; Kirkpatrick \& Lock, 1996). Furthermore, Gonzalez and Guillen (2002) claim that leadership has three dimensions, namely: a technical, a psycho-emotive and an ethical dimension.

According to Covin and Slevin (1989) Entrepreneurial Orientation consists of pro-activeness, risk-taking and innovativeness that enhance business performance. Morris (1997) defines entrepreneurship as a value adding process in an enterprise, and Kaufman and Dant (1998) describe entrepreneurship as a combination of behavioural 
characteristics of the entrepreneur which means: the way they operate and the activities that they are involved in. Hence, these differing views on entrepreneurship highlight the fact that an exact definition of entrepreneurship cannot be limited to a one-dimensional perspective only, rather on a combination of wide-ranging philosophies that collectively describe the phenomenon.

The positive relationship between entrepreneurship and organizational wealth creation, profitability and growth has been illustrated empirically by Antoncic and Hisrich (2004) and Goosen et al. (2002). Likewise, Innovation (Johannessen, Olsen \& Lumpkin, 2001; Verhees \& Meulenberg, 2004); Innovation orientation (Manu \& Sriram, 1996); Pro-activeness (Kickul \& Gundry, 2002); Entrepreneurial orientation (Covin \& Slevin, 1994; Morris \& Sexton, 1996); Entrepreneurial proclivity (Matsuno, Mentzer \& Özsomer, 2002) and Creativity (Fillis, 2002; Im \& Workman, 2004) which are claimed to be elements of entrepreneurship have also been positively linked to various measures of organizational performance.

The integration of the abovementioned dimensions of entrepreneurship (Covin \& Slevin, 1989) and leadership (Gonzalez \& Guillen, 2002) create a complex entrepreneurial leadership construct. Thus, implying that the entrepreneurial leadership construct could consist of: pro-activeness, risk taking propensity, innovativeness, psycho-emotive, technical and ethical dimensions.

Wood's (2002) study suggests that the performance of a small tourism enterprise could be determined by the personality of its entrepreneur. However, given that entrepreneurship is not limited to a one-dimensional perspective, but a combination of wide-ranging philosophies that collectively describe the phenomenon, and leadership is also defined as a multidimensional construct, which consists of the technical, psycho-emotive and the ethical dimensions (Gonzalez \& Guillén, 2002), it suggests that entrepreneurial leadership would likewise influence business performance.

According to Gonzalez and Guillen (2002) the technical dimension of leadership is a measure of the effectiveness of the leader's influence on the followers. The psycho-emotive dimension of leadership refers to the individual characteristics and social skills of the leader, which could create a favourable climate for follower support (González \& Guillén, 2002). Ireland et al. (2003) refer to this dimension as 'Social Capital' and differentiate between what they call 'internal social capital' and 'external social capital'. They further describe internal social capital as inter- and intra-relationships between the individuals of the same firm and external social capital as relationships between the individuals and members of other organizations, which could lead to value creation. In this regard the relationships between owner-managers and employees could be regarded as internal social capital, and relationships between the owner-managers and individuals or organizations external to the venture could be regarded as external social capital. Goleman (1998) supports these views and regards social skills as the key leadership qualities to manage the relationships effectively. The psycho-emotive dimension of leadership therefore describes the attractiveness of the leader's social influence on the followers.

The ethical dimension of leadership mentions how right or good the intensions of a leader are and how morally correct a leader behaves (González \& Guillén, 2002). The importance of an ethical orientation in the contemporary business practices is highlighted by various prominent reports on corruption, fraud and white collar crimes. Ashkanasy and Weierter (cited in Parry, 1998) have highlighted how a follower's self-efficacy and self awareness can improve the leader's ethical responsibility. Although, the ethical behaviour of the followers depends upon the direction and the performance standards set by their organizational leaders (Spangenberg \& Theron, 2005). Given this, a leadership construct without an ethical dimension would therefore seem to be incomplete. Engelbrecht, Van Aswegen and Theron (2005) have also emphasized the importance of positive relationships between transformational leaders and the ethical climate and ethical values in an organization. They state that in organizations where the leaders behave ethically and make ethical decisions, there should be a climate of ethical values. Moreover, high standards of business ethics can only be achieved if there is a 'continuous commitment, and an enforcement and modelling of leadership' in organizations (Banerji \& Krishnan, 2000). London (1999) argues that ethical business values like honesty, fairness, mutual respect, and kindness and by just doing well for others, benefits leaders in building trust and developing good relationships with followers. It is therefore relevant to note that in the tourism industry, the owner-managers of small enterprises who abide by a code of ethics perform better (Wood, 2002).

Gupta et al. (2004) define entrepreneurial leadership as 'leadership that creates visionary scenarios used to assemble and mobilize a 'supporting cast' of participants who become committed by the vision to the discovery and exploitation of strategic value creation'. Swiercz and Lydon (2002) define entrepreneurial leaders as 'individuals who initiate, develop and manage entrepreneurial organizations'. Ireland et al. (2003) define entrepreneurial leadership on the basis of, Covin and Slevin (2002); Ireland and Hitt (1999) and Rowe's (2001) views as 'the ability to influence others to manage resources strategically in order to emphasize both opportunity-seeking and advantageseeking behaviours'. From these views it seems that entrepreneurial leaders have the ability to explore their environments, identify opportunities that could be exploited whilst also motivating others to actively participate in this process towards value creation.

Gupta et al.'s (2004) two-dimensional model of entrepreneurial leadership was validated and measured in a cross-cultural context. The model was established as a universally endorsed model however, the societal differences became unfavourable to its effectiveness. Gupta et al.'s (2004) two dimensional model and their relevant roles and attributes are listed in Table 1. The model accommodates all the abovementioned dimensions of the integrated entrepreneurship and leadership constructs excluding an ethical dimension. 
While Gupta et al. (2004) have comprehensively listed entrepreneurial leadership dimensions; they claim that entrepreneurial leaders 'do not focus on moral ideology', hence their model lacks an ethical dimension. They emphasize building commitment through 'an active, creative, and a discovery-driven' exploitation of opportunities in the environment, and focus on 'customers, products, achieving results, and wealth creation'. Spangenberg and Theron's (2005) study describing the development of an ethical leadership inventory however emphasizes the role of ethics in high performing organizations. Hence the following questions: Does size of an organization determine the ethical behaviour of its leaders or is it more appropriate for large organizations to have ethical leaders? Does an ethical behaviour impact negatively on the other dimensions of the combined entrepreneurial leadership construct? How will therefore ethical behaviour be moderated by a combination of market orientated and relationship marketing orientated approaches, and how will it influence business performance? These questions have remained un-answered, due to lack of research in the area.

Table 1: Entrepreneurial leadership characteristics

\begin{tabular}{|c|c|c|}
\hline Dimensions & Roles & Attributes \\
\hline \multirow{3}{*}{ Scenario enactment } & $\begin{array}{l}\text { Framing the } \\
\text { challenge }\end{array}$ & $\begin{array}{l}\text { Performance } \\
\text { orientation } \\
\text { Ambitious } \\
\text { Informed } \\
\text { Extra insight }\end{array}$ \\
\hline & $\begin{array}{l}\text { Absorbing } \\
\text { uncertainty }\end{array}$ & $\begin{array}{l}\text { Visionary } \\
\text { Foresight } \\
\text { Confidence builder }\end{array}$ \\
\hline & Path clearing & $\begin{array}{l}\text { Diplomatic } \\
\text { Bargainer } \\
\text { Convincing } \\
\text { Encouraging }\end{array}$ \\
\hline \multirow{2}{*}{ Cast enactment } & $\begin{array}{l}\text { Building } \\
\text { commitment }\end{array}$ & $\begin{array}{l}\text { Inspirational } \\
\text { Enthusiastic } \\
\text { Team builder } \\
\text { Improvement } \\
\text { orientated }\end{array}$ \\
\hline & Specifying limits & $\begin{array}{l}\text { Integrator } \\
\text { Intellectually } \\
\text { stimulating } \\
\text { Positive } \\
\text { Decisive }\end{array}$ \\
\hline
\end{tabular}

Source: Adapted from Gupta et al. (2004).

\section{Market orientation}

The positive relationship between market orientation and a firm's performance has been researched and documented by many (Foley \& Fahy, 2004; Homburg, Krohmer \& Workman Jr., 2004; Im \& Workman Jr., 2004; Verhees \& Meulenberg, 2004; Agarwal, Erramilli \& Dev, 2003; Jones, Busch \& Dacin, 2003). However the seminal work of Kohli \& Jaworski (1990) and Narver \& Slater (1990) stimulated subsequent research on the relationship between market orientation and business performance. According to Kohli and Jaworski (1990) the generation of marketing intelligence, the dissemination of intelligence and responsiveness to the acquired intelligence together form market orientation. Narver and Slater (1990) propose the behavioural components such as customer orientation, a competitor orientation and inter-functional coordination, as part of market orientation. Furthermore, Pulendran et al. (2000) emphasize four antecedent factors such as the top management, the organizational systems, interdepartmental dynamics and a reward system orientation that could subsequently influence market orientation. However, according to Harris and Ogbonna (2001) leadership style is also a critical antecedent of market orientation, moreover Harris and Ogbonna (2001) found that a participative and a supportive leadership style as facilitating the development of market orientation. Guo (2002) adds to this insight by arguing that superior customer value is a mediator that connects market orientation to performance. With such multiple contexts, it is important to note that relationship marketing on the other hand 'focuses on the individual buyer and seller relationships and that both parties in each individual buyer and seller relationship benefit' (Sin et al., 2005). This therefore suggests that if market orientation and relationship marketing orientation, both as strategic orientations are employed in tandem, superior customer value (satisfaction) can be obtained which will eventually result in organizational performance.

\section{Relationship marketing orientation}

If relationship marketing means, that 'an organization is engaged in proactively creating, developing and maintaining committed, interactive and profitable exchanges with selected customers and partners' (Harker, 1999), then small tourism enterprises should be able to benefit from forming sustainable relationships with relevant stakeholders. These sustainable relationships should eventually permeate in improved business performance. That is consequently why relationship marketing replaced the transactional marketing paradigm which previously focused on the 4P's approach (Grönroos, 1999). The main focus of relationship marketing is to attract, maintain and enhance customer relationships (Berry, 1983). The theoretical congruence between entrepreneurship and relationship marketing (and especially so) in small firms was illustrated by Zontanos and Anderson (2004) and Day et al. (1998). The fusion of the entrepreneurial and (ethical)leadership concepts therefore pose the question: How would the incorporation of an ethical leadership construct along with the entrepreneurship construct affect the relationship between the ethical entrepreneurial leadership construct and the relationship marketing construct?

Relationship marketing orientation is a multi-dimensional construct consisting of the following six components: trust; bonding; communication; shared values; empathy; and reciprocity (Sin et al., 2002). And a positive relationship between relationship marketing orientation and business performance has been empirically proven (Sin et al., 2005; Tse et al., 2004; Sin et al., 2002). While a positive relationship between entrepreneurship and organizational performance as well as between relationship marketing orientation and organizational performance has been established, it can be assumed that there would likewise be a positive relationship between ethical entrepreneurial 
leadership and organizational performance, strengthened by relationship marketing orientation.

\section{Small and micro tourism venture performance}

Murphy, Trailer and Hill (1996) differentiate the financial and the operational performance measures, to evaluate entrepreneurial businesses. The financial performance measures include return on assets (ROA), return on investments (ROI), and turnover (TO), profitability and income. Typically, the operational performance measures include market share and relative quality. Murphy et al. (1996), made a further distinction between the objective (quantitative) and the subjective (qualitative) measures of performance data. Covin and Slevin (1989) found that subjective measures of performance are better than objective measures of performance in assessing the small and micro enterprise performance. In the same context Wood (2002) asserts that financial criteria as performance measures would not adequately cover the varied goals of owner-managers in small businesses.

A combination of organizational variables like change in turnover, profits, number of employees in the previous operational year, customer spending, and customer numbers, were used by Wood (2002) to empirically measure small tourism venture performance. Morrison and Teixeira (2004) claim that bedroom occupancy rate; annual revenue; breakeven-point and guest satisfaction are the primary performance indicators that are used by the owner-managers of tourism enterprises. Lerner and Haber (2000) state that the use of the numbers of tourists (nights of accommodation or visits) could also be used as a performance measure for tourism ventures. However, it seems that a subjective multidimensional performance construct can be used, to measure performance of small and micro tourism enterprises, in which the owner-managers are asked to record their perceptions regarding the performance of their businesses relative to their main competitors in terms of: occupancy rate, numbers of visitor, market share, growth rate, price charged, quality of service and client satisfaction. The combined responses to these performance variables could then be used to calculate a performance index.

\section{Discussion, conclusions and recommendations for further research}

If Gupta et al. (2004) claim that entrepreneurial leaders exploit their environments to create opportunities for themselves without a focus on moral values, then based on this, the ethical practices of entrepreneurial leaders could be questioned. Additionally, Gupta et al. (2004) distinguishes between value-based leadership and entrepreneurial leadership by contrasting their respective moral ideological focus. This may mean that entrepreneurial leaders are less trustworthy and hence, it may negatively impact on their abilities to form sustainable relationships. Furthermore, it will result in less sustainable business performance. Corporate governance guidelines demand ethical focus, which means that entrepreneurial leaders will therefore have to focus on ethical content.
Spangenberg and Theron (2005) have identified the importance of ethical dimensions in large organizations. No studies have so far, investigated the ethical content of entrepreneurial leaders, hence future studies can investigate this phenomenon.

It could be further argued that entrepreneurs who focus less on ethics, take higher levels of risk, suggesting that in a high risk environment, the ethical component of entrepreneurial leaders is lower, compared to less risk environment, where the ethical values could be higher. Conversely, it may mean that in enterprises where inter-functional coordination is low, higher risk behaviour and consequently lower ethical behaviour exists. These phenomena have however not been investigated as no studies indicate evidence to this.

Moreover, entrepreneurs who function within high-risk levels are more likely to be market orientated (Harris \& Ogbona, 2001). High market orientation level reduces uncertainty in the business and therefore lowering the need for taking risks (Estebau et al., 2002). Although, low risk can be taken along with pro-activeness which is another capability of an entrepreneur to take calculated risks (Goleman, 1998). Since, small companies are more responsive and pro-active towards market orientation (Becherer et al., 2001), it would therefore appear that proactive entrepreneurs could use market orientation as a mechanism to reduce risk.

According to Spangenberg and Theron (2005) ethical leaders facilitate trust. It is therefore expected that high ethical behaviours, will improve trust levels in a business relationship. Trust, however develops over time, to influence customer attitudes positively (Johnson et al., 2003). High levels of ethics would relate to higher levels of trust, shared values, bonding, empathy and eventually also reciprocity.

While, Matear, et al. (2002) found that higher levels of innovation positively contribute towards performance when moderated by market orientation. However, those enterprises which are low in market orientation are less likely to be innovative (Agarwal et al., 2003). The entrepreneurial leader with high levels of innovation and customer and competitor orientation is therefore expected to affect the business performance positively.

The psycho-emotive dimension of leadership reflects many of the emotional intelligence dimensions of Goleman (1998). The higher the emotional quotient (EQ) of an entrepreneurial leader, the more customer orientated the business is, as the EQ positively contributes to competitive advantage. Higher EQ level has been linked to improved relationship building (Goleman, 1998). Similarly leaders with ethical orientation, contribute to the development of trust in relationships as well as to the performance of the business enterprise (Engelbrecht et al., 2005). Hence, it confirms that higher EQ level does influence competitive orientation, and/or inter-functional co-ordination of an enterprise.

Small firms generally lack strategic orientation (Zontanos \& Anderson, 2004), but market orientation and relationship 
marketing orientation are both strategic orientations (Sin et al., 2005) and therefore, it seems as if small firms lack market orientation and relationship marketing orientation. The influence of entrepreneurial leaders on the choice of the appropriate blend of market orientation and relationship marketing orientation in an enterprise will result in different levels of performance. The combined effect of entrepreneurial leadership, market orientation and relationship marketing orientation on small enterprise performance should therefore be empirically investigated in order to establish the exact nature and extent of these relationships.

\section{Limitations of the study}

This article theoretically establishes the relationship between the identified constructs however; the significance of the nature and extent of the interrelationship between these constructs has not been empirically verified within South Africa's small tourism businesses.

\section{References}

Agarwal, S., Erramilli, M.K. \& Dev, C.S. 2003. 'Market orientation and performance in service firms: Role of innovation', Journal of Services Marketing, 17(1): 68-82.

Antoncic, B. \& Hisrich, R.D. 2004. 'Corporate entrepreneurship contingencies and organizational wealth creation', Journal of Management Development, 23(6): 518550 .

Banerji, P. \& Krishnan, V.R. 2000. ,Ethical preferences of transformational leaders: An empirical investigation', Leadership \& Organization Development Journal, 21(8): 405-413.

Barling, J., Slater, F. \& Kelloway, E.K. 2000. 'Transformational leadership and emotional intelligence: An exploratory study', Leadership \& Organization Development Journal, 21(3): 157-161.

Baum, J.R., Kirkpatrick, S.A \& Locke, E.A. 1998. 'A longitudinal study of the relation of vision and vision communication to venture growth in entrepreneurial firms', Journal of Applied Psychology, 83(1): 43-54.

Becherer, R.C., Halstead, D. \& Haynes, P. 2001. 'Market orientation in sme's: effects of the internal environment', Journal of Research in Marketing \& Entrepreneurship, 3(1): $1-17$.

Berry, L.L. 1983. 'Relationship marketing', In Berry, L.L., Shostack, G.L. \& Upah, G.D. (Eds.). Emerging perspectives on service marketing. Chicago: American Marketing Association.

Brown, L. 2007. 'Reflection on 2007 Western Cape Provincial Budget'. Speech presented at the breakfast hosted by The Institute of Directors of Southern Africa, Cape Town.
Covin, J.G. \& Slevin, D.P. 1989. 'Strategic management of small firms in hostile and benign environments', Strategic Management Journal, 10(1): 75-87.

Covin, J.G \& Slevin, D.P. 1994. 'Corporate entrepreneurship in high and low technology industries: A comparison of strategic variables, strategy patterns and performance in global markets', Journal of Euro-Marketing, 3(3): 99-127.

Covin, J.G. \& Slevin, D.P. 2002. 'The entrepreneurial imperatives of strategic leadership'. In Hitt, M.A., Ireland, R.D., Camp, S.M. \& Sexton, D.L. (Eds.). Strategic entrepreneurship: creating a new mindset: 309-327. Oxford: Blackwell Publishers.

Day, J., Dean, A.A. \& Reynolds, P.L. 1998. 'Relationship marketing: Its key role in entrepreneurship', Long Range Planning, 31(6): 828-837.

Engelbrecht, A.S., van Aswegen, A.S \& Theron, C.C. 2005. 'The effect of ethical values on transformational leadership and ethical climate in organizations', South African Journal of Business Management, 36(2): 19-26.

Esteban, Á., Millán, Á., Molina, A. \& Martín-Consuegra, D. 2002. 'Market orientation in service. A review and analysis', European Journal of Marketing, 36(9/10): 1003-1021.

Farrell, M.A. 2000. 'Developing a market-oriented learning organization', Australian Journal of Management, 25(2): 201-223.

Fillis, I. 2002. An 'Andalusian dog or a rising star? Creativity and the marketing/entrepreneurship interface', Journal of Marketing Management, 18: 379-395.

Foley, A. \& Fahy, J. 2004. 'Towards a further understanding of the development of market orientation in the firm: A conceptual framework based on the market-sensing capability', Journal of Strategic Marketing, 12(4): 219-230.

Goleman, D. 1998. 'What makes a leader?' Harvard Business Review, 76(6): 93-102.

González, T.F. \& Guillén, M. 2002. 'Leadership ethical dimension: A requirement in TQM implementation', The TQM Magazine, 14(3): 150-164.

Goosen, C.J., de Coning, T.J. \& Smit, E.v.d.M. 2002. 'Corporate entrepreneurship and financial performance: The role of management', South African Journal of Business Management, 33(4): 21-27.

Grönroos, C. 1999. 'Relationship marketing: A change in paradigm and a focus on determinants of success', Journal of Business Research, 46(3): 327-335.

Guo, C. 2002. 'Market orientation and business performance. A framework for service organizations', European Journal of Marketing, 36(9/10): 1154-1163. 
Gupta, V., MacMillan, I.C. \& Surie, G. 2004. 'Entrepreneurial leadership: Developing and measuring a cross-cultural construct', Journal of Business Venturing, 19: 241-260.

Harris, L.C. \& Ogbonna, E. 2001. 'Leadership style and market orientation: An empirical study’, European Journal of Marketing, 35(5/6): 744-764.

Harker, M.J. 1999. 'Relationship marketing defined? An examination of current relationship marketing definitions', Marketing Intelligence and Planning, 17(1): 13-20.

Homburg, C., Krohmer, H. \& Workman Jr., J.P. 2004. 'A strategy implementation perspective of market orientation', Journal of Business Research, 57: 1331-1340.

Im, S. \& Workman, J.P. 2004. 'Market orientation, creativity, and new product performance in high-technology firms', Journal of Marketing, 68(April): 114-132.

Ireland, R.D. \& Hitt, M.A. 1999. 'Achieving and maintaining strategic competitiveness in the $21^{\text {st }}$ century: The role of strategic leadership', Academy of Management Executive, 13(1): 43-57.

Ireland, R.D., Hitt, M.A. \& Sirmon, D.G. 2003. 'A model of strategic entrepreneurship: The construct and its dimensions', Journal of Management, 29(6): 963-989.

Johnson, J.T. Barksdale Jr., H.C. \& Boles, J. S. 2003. 'Factors associated with customer willingness to refer leads to sales people', Journal of Business Research, 56: 257-263.

Jones, E., Busch, P. \& Dacin, P. 2003. 'Firm market orientation and salesperson customer orientation: Interpersonal and intrapersonal influences on customer service and retention in business-to-business buyer-seller relationships', Journal of Business Research, 56: 323-340.

Johannessen, J., Olsen, B. \& Lumpkin, G.T. 2001. 'Innovation as newness: What is new, how new and to whom?' European Journal of Innovation Management, 4(1): 20-31.

Kaufmann, P.J. \& Dant, R.P. 1998. 'Franchising and the domain of entrepreneurship research', Journal of Business Venturing, 14: 5-16.

Kickul, J. \& Gundry, L.K. 2002. 'Prospecting for strategic advantage: The proactive entrepreneurial personality and small firm innovation', Journal of Small Business Management, 40(2): 85-97.

Kirkpatrick, S.A. \& Locke, E.A. 1996. 'Direct and indirect effects of three core charismatic leadership components on performance and attitudes', Journal of Applied Psychology, 81(1): 36-51.

Kohli, A. \& Jaworski, B. 1990. Market orientation: The construct, research propositions and managerial implications', Journal of Marketing, 54(April): 1-18.
Lafferty, B.A., \& Hult, G.T.M. 2001. 'A synthesis of contemporary market orientation perspectives', European Journal of Marketing, 35(1/2): 92-109.

Langerak, F. 2003. 'The effect of market orientation on positional advantage and organizational performance', Journal of Strategic Marketing, 11: 93-115.

Lerner, M. \& Haber, S. 2000. 'Performance factors of small tourism ventures: The interface of tourism, entrepreneurship and the environment', Journal of Business Venturing, 16: 77-100.

London, M. 1999. 'Principled leadership and business diplomacy', Journal of Management Development, 18 (2): 170-192.

Makhitha, K.M. 2001. 'Marketing strategies used by the small, medium and micro enterprises (SMME) in the tourism Sector'. Unpublished Master's in Commerce thesis, Rand Afrikaans University, Johannesburg.

Manu, F.A. \& Sriram, V. 1996. 'Innovation, marketing strategy, environment, and performance', Journal of Business Research, 35: 79-91.

Matear, S., Osborne, P., Garrett, T. \& Gray, B.J. 2002. 'How does market orientation contribute to service firm performance? An examination of alternative mechanisms', European Journal of Marketing, 36(9/10): 1058-1075.

Matsuno, K., Mentzer, J.T. \& Özsomer, A. 2002. 'The effects of entrepreneurial proclivity and market orientation on business performance', Journal of Marketing, 66(July): 18-32.

Morris, M.H. 1997. Entrepreneurial intensity: Sustainable advantage for individuals, organizations and societies, Westport, CT: Quorum Books.

Morris, M.H. \& Sexton, D.L. 1996. 'The concept of entrepreneurial intensity: Implications for company performance', Journal of Business Research, 36(1): 5-13.

Morrison, A., Rimmington, M. \& Williams, C. 1999. Entrepreneurship in the hospitality, tourism and leisure industries. Oxford: Butterworth-Heinemann.

Morrison, A. \& Teixeira, R. 2004. 'Small business performance: A tourism sector focus', Journal of Small Business and Enterprise Development, 11(2): 166-173.

Murphy, G.B., Trailer, J.W. \& Hill, R.C. 1996. 'Measuring performance in entrepreneurship research', Journal of Business Research, 36: 15-23.

Naidoo, S. 2004. 'Tourism growth 'outperforms other sectors’, Business Day. 4 February, 2.

Narver, J.C. \& Slater, S.F. 1990. 'The effect of a market orientation on business profitability', Journal of Marketing, 54(4): 20-35. 
Parry, K.W. 1998. 'Leadership profiles beyond 2000: how Australian leadership is different', Address to the Senior Executive Service of the Australian Public Service; National Press Club, Canberra, 16 April.

Pulendran, S., Speed, R. \& Widing II, R.E. 2000. 'The antecedents and consequences of market orientation in Australia', Australian Journal of Management, 25(2): 119143.

Rowe, W.G. 2001. 'Creating wealth in organizations: The role of strategic leadership', Academy of Management Executive, 15(1): 81-94.

Sin, L.Y.M., Tse, A.C.B, Yau, O.H.M., Lee, J.S.Y. \& Chow, R.P.M. 2002. 'The effect of relationship marketing orientation on business performance in a service-oriented economy', Journal of Services Marketing, 16(7): 656-676.

Sin, L.Y.M., Tse, A.C.B., Yau, O.H.M., Chow, R.P.M. \& Lee, J.S.Y. 2005. 'Market orientation, relationship marketing orientation, and business performance: The moderating effects of economic ideology and industry type', Journal of International Marketing, 13(1): 36-57.

Spangenberg, H. \& Theron, C.C. 2005. 'Promoting ethical behaviour through leadership of ethics: The development of the ethical leadership inventory (ELI)', South African Journal of Business Management, 36(2): 1-18.

Swiercz, P.M. \& Lydon, S.R. 2002. 'Entrepreneurial leadership in high-tech firms: a field study', Leadership and Organizational Development Journal, 23(7): 380-389.

Tse, A.C.B., Sin, L.Y.M., Yau, O.H.M., Lee, J.S.Y. \& Chow, R. 2004. 'A firm's role in the marketplace and the relative importance of market orientation and relationship marketing orientation', European Journal of Marketing, 38(9/10): 1158-1172.

Verhees, J.H.M \& Meulenberg, M.T.G. 2004. 'Market orientation, innovation, and performance in small firms', Journal of Small Business Management, 42(2): 134-154.

Wolff, S.B., Pescosolido, A.T. \& Druskat, V.U. 2002. 'Emotional intelligence as the basis of leadership emergence in self-managing teams', The Leadership Quarterly, 13: 505-522.

Wood, E.H. 2002. 'An analysis of the predictors of business performance in small tourism and hospitality firms', International Journal of Entrepreneurship and Innovation, 3(3): 201-210.

Zontanos, G. \& Anderson, A.R. 2004. 'Relationships, marketing and small business: An exploration of links in theory and practice', Qualitative Market Research: An International Journal, 7(3): 228-236. 